\title{
Ecology and Management of Black Walnut (Juglans nigra L.) in Hungary
}

\author{
Károly Rédei ${ }^{1}$, Marianna Takács ${ }^{1}$, Tamás Kiss ${ }^{2}$, Zsolt Keserü2*
}

(1) University of Debrecen, Faculty of Agricultural and Food Sciences and Environmental Management Böszörményi Út 138., H-4032 Debrecen, Hungary; (2) National Agricultural Research and Innovation Centre, Forest Research Institute, Püspökladány Experimental Station, Farkassziget 3, H-4150 Püspökladány, Hungary

* Correspondence: e-mail: keseruzs@erti.hu

\begin{abstract}
Citation: RÉDEI K, TAKÁCS M, KISS T, KESERÛ́ ZS 2019 Ecology and Management of Black Walnut (Juglans nigra L.) in Hungary. Southeast Eur for 10 (2): 187-191. DOI: https:// doi.org/10.15177/seefor.19-12

Received: 6 Mar 2019; Revised: 7 Jun 2019; Accepted: 23 Jun 2019; Published online: 15 Aug 2019
\end{abstract}

\begin{abstract}
Background and Purpose: Black walnut (Juglans nigra L.) was one of the first forest tree species introduced and acclimated from North America to Europe in the $17^{\text {th }}$ century. Although native to North America, black walnut is now naturalized and widely planted throughout Europe. In Hungary, this species has played an important role in forest management. Black walnut can grow on various sites, but careful site selection and well-planned management practices are needed to produce successful plantations. Due to the increasing interest in black walnut growing in many countries this study complied with the aim of giving a summary on the base of research and improvement connected with the species over the past decades. Materials and Methods: Black walnut produces a well-closing, favourably differentiated stand structure in consequence of the great genetic diversity of single trees. It utilizes well the leaks of the tending cuttings. In this manner, because of its quick height growth, the systematic, individual selective method can be favourably combined with more frequent stem number reduction. The objective of tending should be to produce a high proportion of good quality saw logs from stands of yield class I, II, III and IV, and some other smaller-dimension industrial wood from stands of yield class V and VI.

Conclusions: In Hungary, black walnut is one of the most valuable exotic tree species, mainly because of its wood excessively used in furniture industry. Black walnut is used in furniture industry both as solid wood and veneer. This species is among the most expensive furniture woods in the world due to its appealing surface figure and colour. Its wood is also used for making musical instruments, turned and carved ornaments, statues and marquetry. Black walnut stands are to be important in carbon sequestration, soil stabilization, and water quality protection as well.
\end{abstract}

Keywords: black walnut (Juglans nigra L.), stand establishment, tending operations and yield, diseases

\section{INTRODUCTION}

Black walnut is one of the most valuable hardwoods in Hungary. Landowners have shown an increasing interest in growing black walnut for high-value timber products. Hungary has much experience in black walnut growing, as it was imported to the country in the eighteenth century [1]. Black walnut forests in Hungary have been established on high-quality as well as on medium-quality sites. The establishment of black walnut stands producing high-quality timber is possible only on sites with adequate moisture and well-aerated and preferably light soils, rich in nutrients and humus. It is a fast-growing species with frequent seed production and relatively high yielding potential. It has a durable and high quality wood, which is used for many purposes $[2,3]$. This paper provides a practice-oriented review for black walnut plantation management based on the relevant Hungarian experiences and research results.

\section{AREA AND TREE CHARACTERISTICS}

In Hungary, black walnut is one of the most valuable exotic tree species, mainly because of its wood excessively used in furniture industry [4]. It was introduced from North America to Europe in the $17^{\text {th }}$ century, and appeared in the $18^{\text {th }}$ century in Hungary. The first plantations of black walnut were established $100-110$ years ago. The area of black walnut is approx. 8000 ha (approx. $0.4 \%$ of the forested area) in the country. Important plantations of black walnuts are found in Tolna, Baranya, Somogy, Bács-Kiskun and Győr- Sopron [3] (Figure 1 and 2). 
Black walnut is a light-demanding tree species and develops straight, cylindrical trunks in close stands. The tree may grow 20-30 m tall, with a 15-18 m useful bole length. The average Diameter at Breast Height (DBH) can reach $0.3-0.4 \mathrm{~m}$ at the age of $80-90$ years [5]. Longitudinal cracks appear on the greyish black bark even in young trees. Leaves are oddly pinnate, just like those of common walnut, but they are serrate with a less intensive odour. The large edible nut ripens in September or October of the same year and drops shortly after the leaves fall. Good seed crops are produced irregularly, perhaps twice in 5 years. Best seed production begins when the trees are about 30 years old and continues for another 40-50 years [5]. The initial root form of black walnut, with its rapidly growing juvenile taproot and wide spreading laterals, is characteristic of species that grow on deep, fine-textured soils $[2,6]$.

\section{SITE REQUIREMENTS}

In Hungary, black walnut grows preferably on plains and thrives on moderately compact, nutrient-rich, moist soils (e.g. flood plains). It grows especially well on deep loams, loess soils, and fertile alluvial deposit. It also grows well on good agricultural soils, but it grows slower on sandy ridges. It tolerates winter frost well, but it is sensitive to early winter and late spring frosts $[2,3,7]$.

In general, soils should be deep (at least $80-90 \mathrm{~cm}$ ), welldrained, and should have a good moisture-holding capacity. Fertile loams and sandy loams with high organic matter and $\mathrm{pH}$ from 6.5 to 7.2 are usually best. Flooding can kill young walnut trees during the growing season. If water remains over the tops of trees for more than 2 days, the trees usually die. Flooding for 3 to 5 days during the dormant season is tolerated, but logs and other debris will often break or bend trees. Young trees recover rapidly from such treatment, but older trees may sustain permanent damage to bark, providing an avenue of entrance for decay $[3,6]$.

\section{PLANTATION ESTABLISHMENT}

\section{Seedlings Management}

In Hungary there are excellent nurseries to provide seedlings for artificial reforestation and afforestation. Seedling quality is generally good, and all seedlings are grown from walnuts collected in the country. Only larger seedlings with healthy root systems are sorted and planted. The grafts are relatively expensive, but provide a known, reproducible, genetic improvement over nursery seedling stock [2].

\section{Planting and Sowing Season}

April and May are generally the most desirable months for planting bare-root walnut seedlings or sowing seeds. Seedlings should be planted after the danger of late freezes. Spring planting provides seedling with time to establish a root system before winter. Autumn planting (October, November) can also be proven successful under certain conditions. However, bare-root seedlings approaching the winter with little root growth and without adequate snow cover or mulch often suffer winter kill $[2,3,7]$.

\section{Layout and Spacing}

Recommended spacing for walnut plantations is 2.52.8 by $0.7-1.0 \mathrm{~m}$ (4000-5000 trees per hectare). This allows for mortality and thinning of undesirable trees during the rotation. Plantation layout is crucial to ease management operations in the future. Rows must be straight in at least one direction to facilitate mowing, spraying, and other silvicultural operations such as soil surface treatments between the rows. In case of sowing, normally 800-1000 kilos of seeds in shell are sown per hectare [2].

\section{Interplanting}

In Hungary black walnut plantations are established as monocultures. Our growing trials with a mixture of black walnut and black locust have shown that black locust outgrows walnut and quickly smothers it [2]. Under no

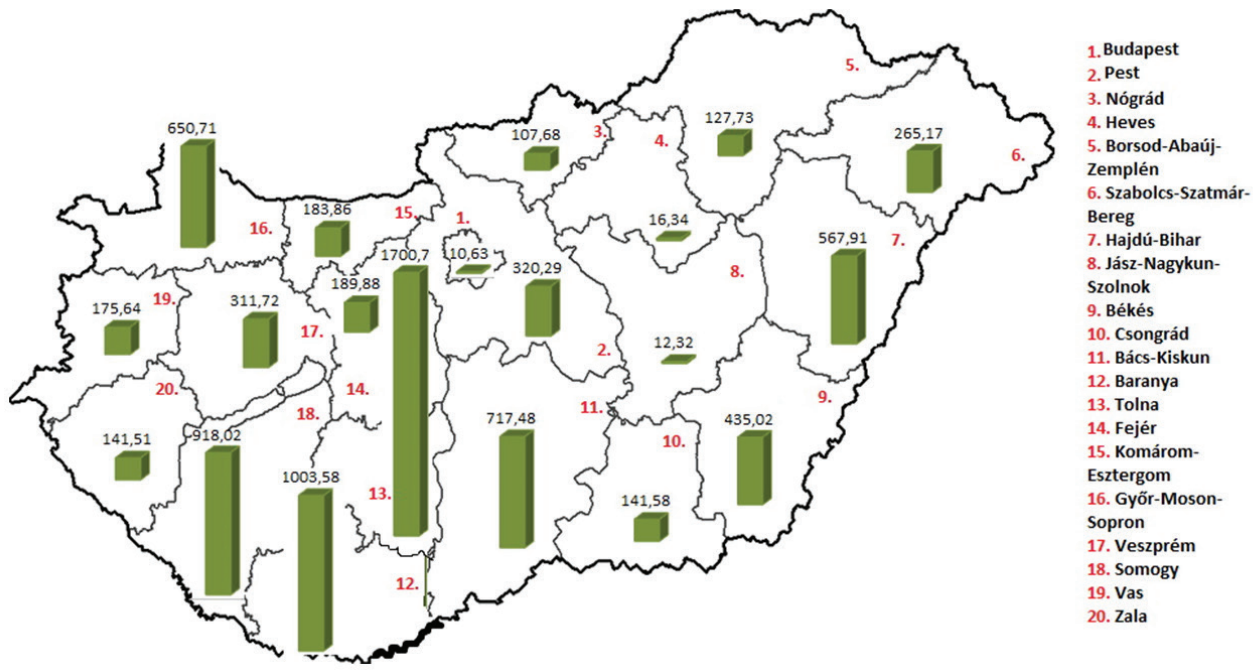

FIGURE 1. Covering of black walnut stands by counties (ha) (Source: Forest Service, 2015). 


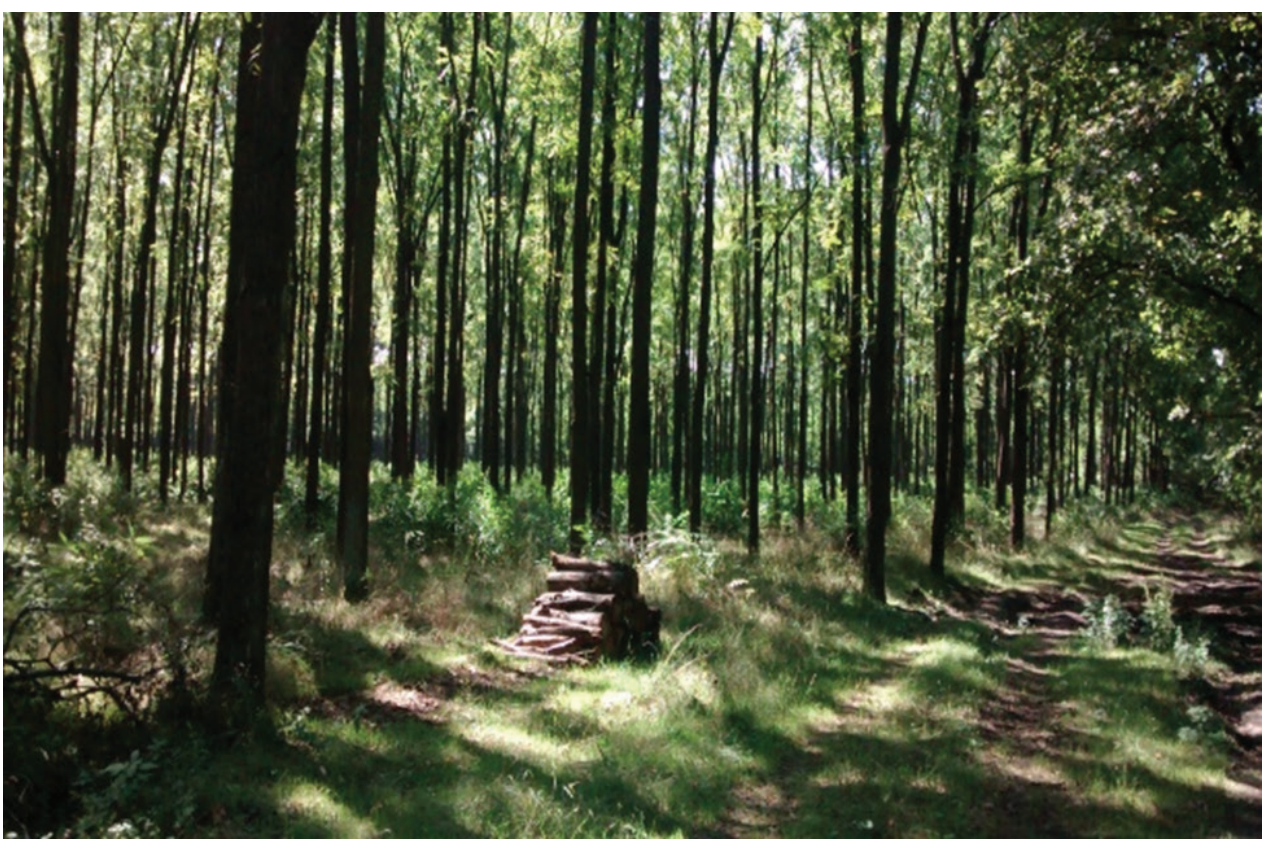

FIGURE 2. Black walnut plantation at the age of 60 years in Central Hungary (Photo: K. Rédei)

circumstances should livestock be grazed in a black walnut plantation. They will eat young trees; the bark of older trees may be stripped and soil compaction will reduce walnut growth. Deer and rabbits can provide forest owners with enough problems caused by animals $[2,6]$.

\section{Weed Control}

Without weed control, black walnut plantations invariably fail or do not grow nearly to their potential. Weed control should be carried out both in the rows by hoeing and between the rows by disk. However, it must be emphasized that cultivation will be required twice during each growing season for trees up to four or five years old. Depth of cultivation must be shallow, because many walnut feeder roots are in the upper layers of the soil and are easily damaged [2].

\section{Pruning}

Apart from weed control, the other important treatment to improve the quality and future value of black walnut is pruning. The purpose of pruning is to develop a straight single stem which will ultimately become a high-value veneer log. Black walnut has an overwhelming tendency to produce multiple shoots caused by insect or frost injury to the terminal bud. These shoots, if not reduced to the single straightest and/or tallest, will produce forks that limit the length of the future log. During carrying out the tending operations, it is necessary to reach a height of 8-10 metres of branch-free stem $[2,6]$. It is known that proper pruning is the factor that a grower can use to greatly increase tree quality and hence the economic value of a walnut plantation. In fact, pruning may double the value of a plantation at harvest age.

\section{TENDING CUTTINGS AND YIELD}

The first tending cutting should be made at about 8-10 years. Poorly formed trees with no potential for straightening, diseased, and very slow-growing trees should be removed. Sprouts should be mowed frequently until dead. Over 18 years thinnings are to be carried out. During the tending cuttings, it is important to take into consideration that populations consist of specimens of varied genetic value (genotypic). Black walnut produces a well closing, favourably differentiated stand structure in consequence of the great genetic diversity of single trees. It utilizes well the leaks of the tending cuttings. In this manner, because of its quick height growth, the systematic, individual selective method can be favourably combined at the more frequent stem number reduction (Table 1 ).

The most important stand structure parameters of black walnut stands at the age of 80 years old (Yield table: (5)) are shown in Table 2.

The objective of tending should be to produce a high proportion of good quality sawlogs from stands of yield class I, II, III and IV; and some other smaller-dimension industrial wood from stands of yield class $\mathrm{V}$ and $\mathrm{VI}$. The mean volume increment, depending on the yield classes, varies between 3.1 and $14.2 \mathrm{~m}^{3} \cdot \mathrm{ha}^{-1} \cdot \mathrm{yr}^{-1}$ [5]. The average rotation age for black walnut stands is $75-85$ years $[2,5,6]$.

\section{DISEASES}

In Hungary, black walnut has no too many damages. A correct choice of species ensures that most black walnut 
TABLE 1. Tending regime for black walnut plantations.

\begin{tabular}{ccc}
\hline Year & Stage/operation & Stem number·ha $^{-1}$ \\
\hline 1 & Planting & $4000-5000$ \\
$2-4$ & Weed controls, replacing dead plants & $3500-4000$ \\
$5-6$ & "Completed stage" & $3000-3500$ \\
$8-10$ & Cleaning - respacing & $2000-2500$ \\
$13-15$ & Cleaning & $1200-1400$ \\
$18-22$ & Pre-commercial thinning & $800-1000$ \\
$25-30$ & Selective thinning & $300-400$ \\
$50-60$ & Increment thinning & $180-200$ \\
$60-75$ & Sanitary cutting (if necessary) & $120-150$ \\
$75-85$ & Harvest cutting & $100-150$ \\
\hline
\end{tabular}

TABLE 2. The most important stand structure parameters of black walnut plantations at the age of 80 years.

\begin{tabular}{cccc}
\hline Yield Class & $\begin{array}{c}\text { Height } \\
(\mathrm{m})\end{array}$ & $\begin{array}{c}\text { Diameter at breast Height } \\
(\mathrm{cm})\end{array}$ & $\begin{array}{c}\text { Volume } \\
\left(\mathrm{m}^{3} \cdot \mathrm{ha}^{-1}\right)\end{array}$ \\
\hline I & 29.5 & 43.6 & 428 \\
II & 25.0 & 37.0 & 315 \\
III & 21.1 & 31.3 & 231 \\
IV & 17.2 & 26.4 & 170 \\
V & 15.1 & 22.4 & 125 \\
VI & 12.8 & 18.9 & 92 \\
\hline
\end{tabular}

plantation schemes are successful. Frost damage appears in the form of suddenly blackened new leaves and shoots. Secondary buds will break and begin growing up and down the stem within a few days after frost. No permanent damage is caused except for the growth of multiple stems that require careful pruning [2]. Dicerca alni Fischer, Hylesinus fraxini Panzer and Colotois pennaria Linné can be mentioned, which may cause damages. Wild animals, mostly wild boar, can damage the fresh sowing, as well as deer and red deer, who can browse on new growth in young black walnut plantations. Fencing plantations against them is expensive but sometimes essential $[2,6]$.

\section{BLACK WALNUT WOOD CHARACTERISTICS AND MARKETING}

Black walnut is an important source of hardwood lumber. The wood is close-grained, heavy and hard; it machines well and accepts a variety of finishes. Its most important wood properties are the followings $[1,4]$ :
- Density $\left(\mathrm{kg} \cdot \mathrm{m}^{-3}\right)$ : air dry $(12 \% \mathrm{MC})=580-640-810$, oven-dry = 560-580, green $=900-980$;

- Shrinkage (\%): radial = 4.8-5.5, tangential = 7.1-7.7; longitudinal $=0.4$, volumetric $=12.0-13.3$;

- Assortments: sliced veneer raw material; sawlogs; short and low quality logs; other industrial wood; firewood;

- Utilisation: Black walnut is used in the furniture industry both as solid wood and veneer. This species is among the most expensive furniture woods in the world for its appealing surface figure and colour. It is important for exquisite interior applications, such as for staircases, flooring and panelling. It is unique for manufacturing hunting arms because of its beauty and strength. The wood is also used for making musical instruments, turned and carved ornaments, statues and marquetry [4];

- Wood prices: There are no fixed prices. In the openair market $1 \mathrm{~m}^{3}$ black walnut wood material costs approx. 130.00 EUR. 


\section{ECOSYSTEM SERVICES, INVASIVENESS}

Black walnut stands are to be important in carbon sequestration, soil stabilization, and water quality protection [8]. They also have a special role in preserving wildlife and environment as a shelterbelt. Black walnut provides good cover and nesting sites for a wide variety of birds and mammals. Deer, red deer, wild boar and rabbits commonly browse leaves and young seedlings, while acorns are eaten by a wide variety of large and small mammals and birds. Black walnut is not considered to be an invasive tree species in Hungary $[2,6]$.

\section{CONCLUSION}

In Hungary, black walnut plantations have not made a significant impact on the supply oftimber. However, if the volume of new plantations is increased, if the plantations are adequately managed and if they are planted on productive sites, the plantations have the potential to improve the future supply of black walnut wood fiber.

\section{REFERENCES}

1. BABOS K, FILLÓ Z, SOMKÚTI E 1979 Useful tree species. Műszaki Könyvkiadó, Budapest, Hungary, 315 p (in Hungarian)

2. FÜHRER E, RÉDEI K, TÓTH B 2008 Plantation Forestry 2. Agroinform Kiadó, Budapest, pp 25-33 (in Hungarian)

3. RÉDEI K, ANTAL B 2017 Black walnut (Juglans nigra L.) as a valuable stand-forming tree species: growing techchnological rewiew. Acta Agraria Debreceniensis 69: 43-48 (in Hungarian)
4. MOLNÁR S, BARISKA M 2002 Wood species of Hungary. Szaktudás Kiadó Ház Budapest, Hungary, pp 102-105

5. PALOTÁS F 1973 Yield of black walnut stands. Erdészeti Kutatások 69: 191-199 (in Hungarian)

6. SÁRVÁRI J Forest from walnut trees. Mezőgazda Kiadó, Budapest, Hungary, $119 \mathrm{p}$ (in Hungarian)

7. BONDOR A, GÁL J 1976 Production of forest propagation material. Mezőgazdasági Kiadó, Budapest, 226 p (in Hungarian)

8. SZENTKIRÁLYI P, KÁLLAY TAMÁSNÉ Walnut. 2006 Mezőgazda Kiadó, Budapest, Hungary, 203 p (in Hungarian) 
